\title{
Thrombotic antiphospholipid syndrome in a child with human immunodeficiency virus: a rare case report
}

\author{
Rong-Jing Dong ${ }^{1,2+}$, Su-Yun Lei ${ }^{1 \dagger}$, Jun $\mathrm{Li}^{3}$, Xin-Ping Yang ${ }^{1}$, Yu-Ye $\mathrm{Li}^{2^{*}}$ and Yun-Gui Zhang ${ }^{1 *}$
}

\begin{abstract}
Background: Antiphospholipid syndrome (APS) is a non-inflammatory autoimmune disorder induced by antiphospholipid antibodies, which occurs exceedingly rarely in pediatric population and even more rarely reported in HIV positive children.
\end{abstract}

Case summary: A case of 11 years old boy had a sudden onset of swelling in his left lower leg along with pain which were worsening gradually. Initially, topical ointment was applied for 1 month which were ineffective in reducing pain and swelling. Instead, the symptoms were aggravated and suddenly spread to the proximal thigh, accompanied by dyskinesia of left lower leg. Both color doppler ultrasonography and vascular CT scan of left lower leg revealed deep venous thrombosis. His serum anti-phospholipid antibodies (aPLs) were tested positive. He was a known case of HIV virological failure with substantial HIV viral load (VL) despite receiving regular antiretroviral therapy (ART). His symptoms improved after giving aggressive antithrombotic and high dose corticosteroid treatments.

Conclusion: When pediatric patients develop thrombotic disease, APS also needs to be ruled out. The autoantibodies levels should be routinely tested to look for recurrent thrombosis in children with HIV/AIDS.

Keywords: APS, Thrombosis, HIV

\section{Background}

Antiphospholipid syndrome (APS) which is also named as Hughes Syndrome, is an autoantibodies-induced autoimmune disease characterized by recurrent arterial or venous thrombosis and/or fetal loss associated with thrombocytopenia and persistently seropositive (usually moderate to high titer elevated) for anti-phospholipid antibodies (aPLs) [1]. The presence of circulating aPLs, including anticardiolipin antibodies (aCLs), lupus

\footnotetext{
*Correspondence: yyeli2000@126.com; 805903562@qq.com

${ }^{+}$Rong-Jing Dong and Su-Yun Lei contributed equally to this work.

${ }^{2}$ Department of Dermatology and Venereology, First Affiliated Hospital of Kunming Medical University, Kunming 650032, China

${ }^{1}$ Yunnan Provincial Hospital of Infectious Disease/Yunnan AIDS Care Center, Kunming 650301, China

Full list of author information is available at the end of the article
}

anticoagulant (LA) and/or anti-beta 2 glycoprotein I $(\beta 2 \mathrm{GPI})$, are risk factor for developing thrombosis in asymptomatic individuals. It has been estimated that approximately 39\% APS patients coexist with venous thromboembolism [2]. The existing studies have showed that HIV infected patients have 2-10-folds increased risk of developing thrombosis as compared with general population [3]. However, the physiological mechanism of the presence of coexisting APS and HIV infection affecting thrombosis process has not been well studied. Herein, we have reported a rare case of a coexistence of APS and asymptomatic HIV-infected child who has developed left lower extremity thrombosis.

(c) The Author(s). 2021 Open Access This article is licensed under a Creative Commons Attribution 4.0 International License, which permits use, sharing, adaptation, distribution and reproduction in any medium or format, as long as you give appropriate credit to the original author(s) and the source, provide a link to the Creative Commons licence, and indicate if changes were made. The images or other third party material in this article are included in the article's Creative Commons licence, unless indicated otherwise in a credit line to the material. If material is not included in the article's Creative Commons licence and your intended use is not permitted by statutory regulation or exceeds the permitted use, you will need to obtain permission directly from the copyright holder. To view a copy of this licence, visit http://creativecommons.org/licenses/by/4.0/ The Creative Commons Public Domain Dedication waiver (http://creativecommons.org/publicdomain/zero/1.0/) applies to the data made available in this article, unless otherwise stated in a credit line to the data. 


\section{Case presentation}

An 11 years old boy had a sudden onset of swelling in his left lower extremity along with pain which were worsening gradually for past 1 month duration. He had no history of fever, headache, cough, chest tightness, chest pain, abdominal pain and diarrhea. His $\mathrm{CD} 4^{+} \mathrm{T}$ lymphocyte cell count was 522 cells $/ \mu \mathrm{L}$ and plasma VL was 943 copies/mL with a blood pressure around 97/69 $\mathrm{mmHg}$ at that time. Initially, topical ointment was applied for 1 month which were ineffective in reducing pain and swelling. Instead, the symptoms were aggravated and suddenly spread to the proximal thigh, accompanied by dyskinesia of left lower leg. The child was a known case of HIV positive since the age of two and was believed to be infected through mother to fetus transmission. He has been taking first-line regimen of ART $(\mathrm{AZT}+3 \mathrm{TC}+\mathrm{NVP})$ since last 4 years when his $\mathrm{CD}^{+} \mathrm{T}$ lymphocyte cell count had reached 346 cells $/ \mu \mathrm{L}$ at that time. The plasma HIV RNA was undetectable after half a year of ART.

His mother was HIV seropositive person. The child had no personal and/or family history of thrombotic diseases. There was no history of any prior surgery, trauma, prolonged bed rest, obesity, smoking and any other common risk factors of thromboembolic events.

On physical examination during hospital admission, the maximum circumference of his left thigh was $38 \mathrm{~cm}$ and the right thigh was $34 \mathrm{~cm}$. The maximum circumference of his left calf was $27 \mathrm{~cm}$ and the right calf was 24 $\mathrm{cm}$. His left lower thigh was inflamed and swollen, accompanied by tenderness and presence of varicose veins.

On hematological tests, his white blood cell (WBC) count was $3.28 \times 10^{9} / \mathrm{L}$ with a $\mathrm{CD}^{+} \mathrm{T}$ lymphocyte cell count of 430 cells $/ \mu \mathrm{L}$, hemoglobin $(\mathrm{Hb})$ was $126 \mathrm{~g} / \mathrm{L}$ and platelets was decreased to $66 \times 10^{9} / \mathrm{L}$. On virology test, HIV RNA was found to be 580 copies $/ \mathrm{mL}$. The coagulation function test showed PT was reported to be $14.0 \mathrm{~s}$ and activated partial thromboplastin time (APTT) was prolonged to $44.3 \mathrm{~s}$. The international normalized ratio (INR) and Fibrinogen (FIB) were 1.16 and $15.1 \mathrm{mg} / \mathrm{L}$ respectively. D-dimer was $6.26 \mathrm{mg} / \mathrm{L}$. C-Reactive Protein (CRP) was $32.14 \mathrm{mg} / \mathrm{L}$, procalcitonin (PCT) was 0.029 $\mathrm{ng} / \mathrm{ml}$ and erythrocyte sedimentation rate (ESR) was 41 $\mathrm{mm} / \mathrm{h}$. The aCLs IgG was at 57 (normal $<22$ ), IgM was at 24 (normal < 10). Anti-neutrophil cytoplasmic antibody (pANCA) and anti- $\beta 2$ GPI antibody were tested positive. In addition, some other autoimmune antibodies were also tested positive: ANA (1:100, granular); dsDNA: +; nucleosome: ++; histone: +; mitochondrial M2: +. Other examinations including liver and kidney function tests were unremarkable.

Color doppler ultrasonography of lower extremity vessels revealed deep venous thrombosis in his left lower leg, accompanied by soft tissue edema and superficial lymphangiectasia. Vascular CT scan of left lower extremity showed extensive mural thrombosis (Fig. 1).

He was then diagnosed HIV complicated with thrombotic antiphospholipid syndrome. $\mathrm{He}$ was initially treated with low molecular weight heparin $(\mathrm{LMWH}) \mathrm{cal}$ cium $3000 \mathrm{IU}$ every $12 \mathrm{~h}$ for 6 weeks followed by warfarin $(1.25 \mathrm{mg} /$ day $)$ for long-term anticoagulant therapy at a target INR of 2.0-3.0. Besides, methylprednisolone ( $40 \mathrm{mg} /$ day) treatment was also given to the patient for ten days which was substituted with $30 \mathrm{mg} /$ day prednisone after that. The prednisone dosage was gradually reduced by $5 \mathrm{mg}$ each time every 2 weeks until reached 5 $\mathrm{mg} / \mathrm{d}$ and maintained for another 2 months. Additionally, antiviral regiment was adjusted to $\mathrm{ABC}+3 \mathrm{TC}+$ $\mathrm{LPV} / \mathrm{r}$ due to his persistent high HIV viremia.

After one month of treatment, the swelling and pain were gradually relieved and vascular ultrasonography on follow up visit had showed the blocked vessel was partial recanalized and platelets count had returned to normal. After 3 months of treatment, his symptoms continued to be ameliorated. However, the aCLs and $\beta 2-\mathrm{GP} 1$ antibody titers were still tested positive. After 6 months of treatment, his $\mathrm{CD}^{+}{ }^{+} \mathrm{T}$ lymphocyte cell count was 633 cells/ $\mu \mathrm{L}$ and HIV RNA was undetectable. His left lower extremity blood vessels were returned to normal. (Table 1 and Fig. 2).

\section{Discussion and conclusions}

The etiology of APS is complex and has not been well delineated. The most popular hypothesis suggested a "two hit " mechanism in pathogenesis of APS. The first hit is the presence of aPLs antibodies and interaction with vascular endothelial cells, neutrophils, platelets and monocytes resulting in endothelial dysfunction and injury. The second hit is the facilitation from predisposing factors like infections, contraceptives, malignancies and genetic susceptibility etc. which eventually leading to thrombotic events $[4,5]$. Common infections associated with APS include typhoid bacillus, hepatitis virus, cytomegalovirus and particularly HIV infection [6-8]. Among APS patients, the incidence of HIV infection was as high as $17.0 \%$ [6].

The HIV virus, as a superantigen that may even resemble some autoantibodies, can induce APS through possible "molecular mimicry" mechanisms. Moreover, HIV virus can directly damage vascular endothelial cells and subsequent generation of autoimmune antibodies. Thus, participating the "double hit" pathway in the development and progress of APS $[9,10]$. The patient we reported had experienced a virological failure with substantial HIV viral load (VL) despite receiving regular ART. It has been reported that the manifestation of APS was positively correlated with HIV viral load level [3, 11]. Some studies have even suggested HIV as a direct 


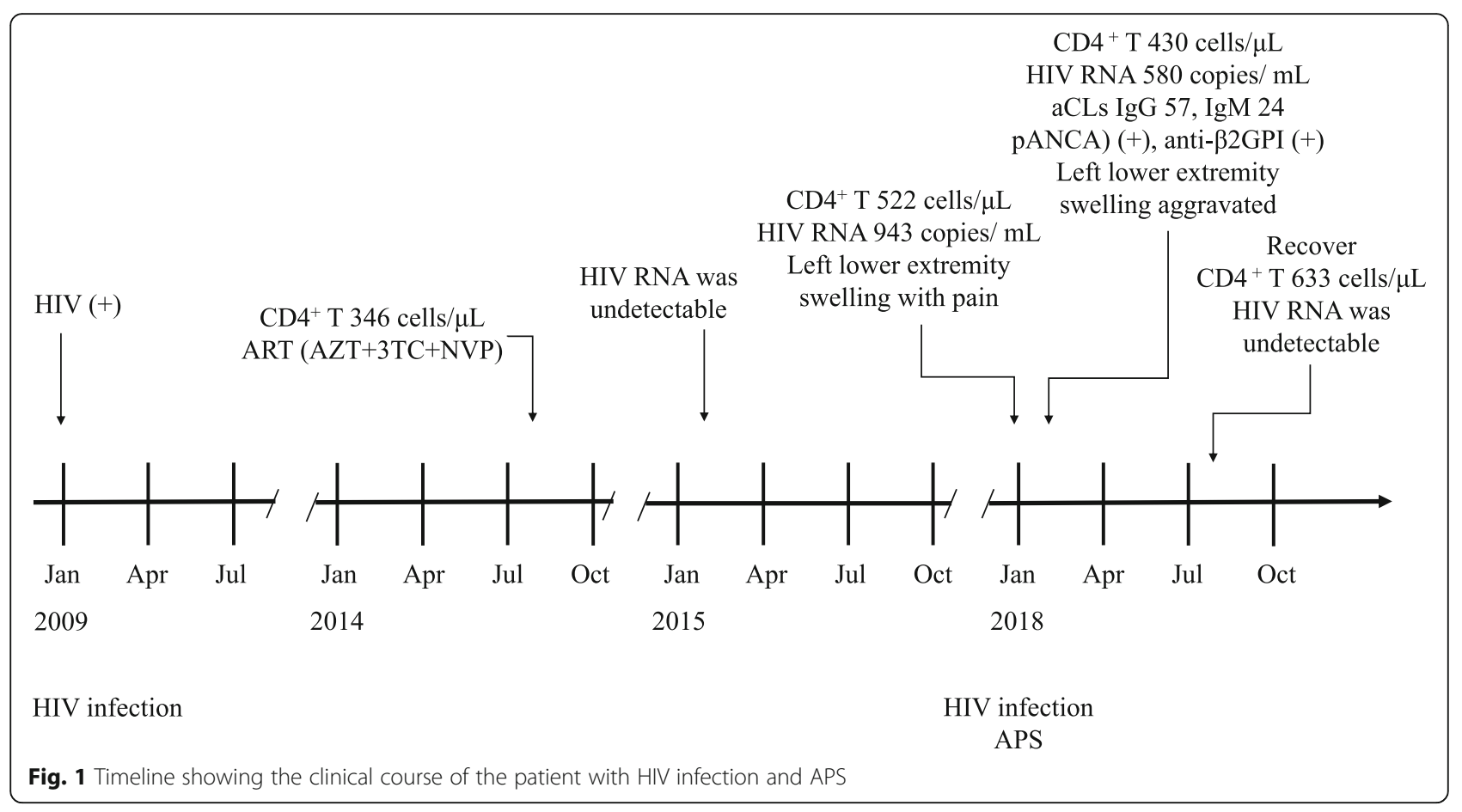

Table 1 Clinical symptoms and Laboratory findings of the patient

\begin{tabular}{|c|c|c|c|}
\hline Time & Clinical symptoms & Laboratory findings & Treatment regimens \\
\hline January 2009 & No & HIV $(+)$ & - \\
\hline August 2014 & No & $\mathrm{CD}^{+} \mathrm{T}$ count: 346 cells $/ \mu \mathrm{L}$ & ART $(A Z T+3 T C+N V P)$ \\
\hline February 2015 & No & HIV RNA: undetectable & ART $(A Z T+3 T C+N V P)$ \\
\hline January 2018 & Left lower extremity swelling with pain & $\begin{array}{l}\text { CD4 }{ }^{+} T \text { count: } 522 \text { cells/ } \mu \mathrm{L}, \text { HIV RNA: } \\
943 \text { copies } / \mathrm{mL}\end{array}$ & $A R T(A Z T+3 T C+N V P)$ \\
\hline February 2018 & $\begin{array}{l}\text { The maximum circumference of his left thigh was } \\
38 \mathrm{~cm} \text { and the right thigh was } 34 \mathrm{~cm} \text {. The } \\
\text { maximum circumference of his left calf was } 27 \mathrm{~cm} \\
\text { and the right calf was } 24 \mathrm{~cm} \text {. His left lower thigh } \\
\text { was inflamed and swollen, accompanied by } \\
\text { tenderness and presence of varicose veins. }\end{array}$ & 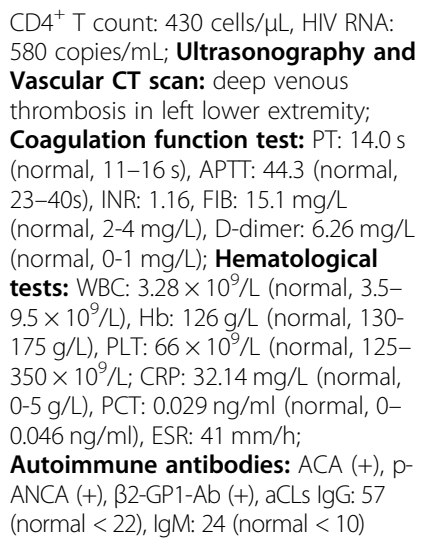 & $\begin{array}{l}\text { ART }(A B C+3 T C+L P V / r), \\
\text { LMWH calcium followed by } \\
\text { warfarin; methylprednisolone } \\
\text { followed by prednisone }\end{array}$ \\
\hline \multirow[t]{2}{*}{ August 2018} & Left lower extremity revascularized & $\begin{array}{l}\mathrm{CD}^{+}{ }^{+} \mathrm{T} \text { count: } 633 \text { cells/ } \mu \mathrm{L}, \text { HIV RNA: } \\
\text { undetectable; }\end{array}$ & $A R T(A B C+3 T C+L P V / r)$ \\
\hline & & $\begin{array}{l}\text { Coagulation function test: PT: } 14.3 \mathrm{~s} \\
\text { (normal, } 11-16 \mathrm{~s} \text { ), APTT: } 21.4 \text { (normal, } \\
\text { 23-40s), INR: } 1.19, \text { FIB: } 1.94 \mathrm{mg} / \mathrm{L} \\
\text { (normal, } 2-4 \mathrm{mg} / \mathrm{L}), \mathrm{D}-\text { dimer: } 1.12 \mathrm{mg} / \mathrm{L} \\
\text { (normal, } 0-1 \mathrm{mg} / \mathrm{L}) \text {; } \\
\text { Autoimmune antibodies: ACA (-), p- } \\
\text { ANCA (-), } \beta 2-\mathrm{GP} 1-\mathrm{Ab}(-) \text {, aCLs lgG: } 19 \\
\text { (normal < 22), lgM: } 4 \text { (normal < 10) }\end{array}$ & \\
\hline
\end{tabular}




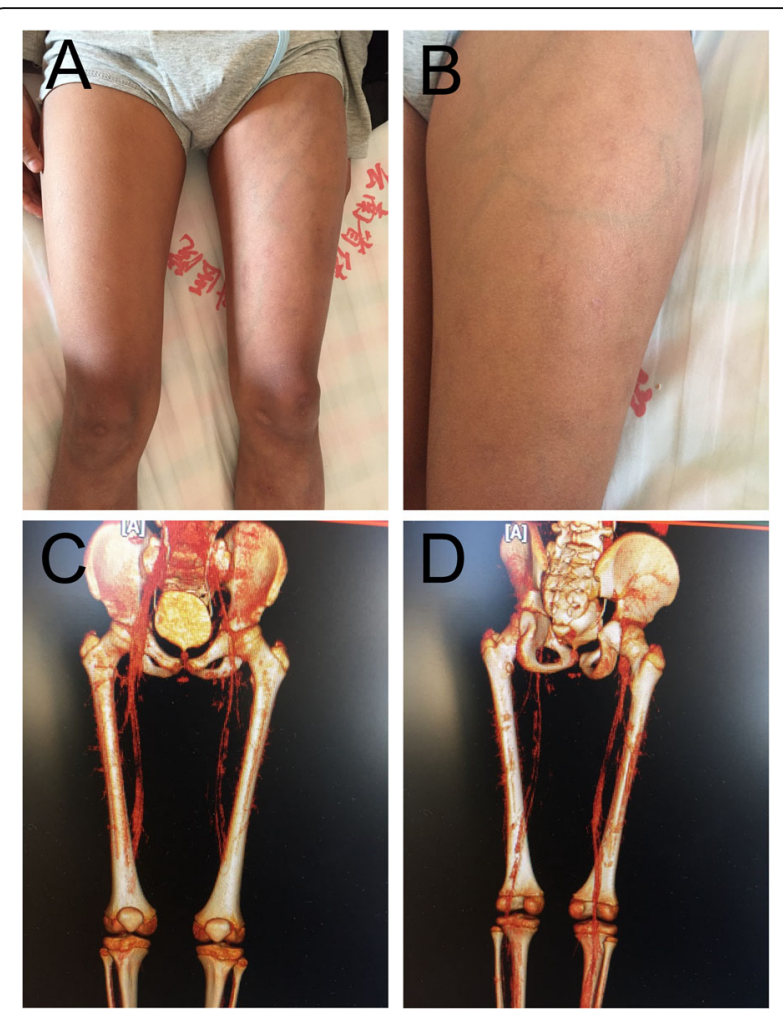

Fig. 2 Clinical and Vascular CT three-dimensional reconstruction images of the patient. $\mathbf{a}, \mathbf{b}$. His left lower extremity thigh was inflamed and swollen with varicose veins. c, d. Vascular CT threedimensional reconstruction showed left lower extremity showed extensive mural thrombosis

trigger of APS onset [12]. Therefore, the occurrence of APS may be associated with high levels of HIV viremia in HIV/AIDS patients.

The superimposed HIV infection might even further increase the risk of thrombosis in APS. The existing studies have showed that when compared with general population, HIV infected patients have $2-10$-folds increased risk of developing thrombosis [8]. Firstly, HIV infection often leads to immunosuppression and affect B cell function resulting in increased production of autoantibodies [13]. Therefore, HIV-infected patients have higher concentrations of aPLs antibodies [14, 15]. Moreover, the deficiency of protein $\mathrm{C}$ and $\mathrm{S}$ and increased platelet activation are risk factors for thrombosis in HIV/AIDS patients [16-18]. Additionally, it has been reported that protease inhibitor (PI) in ART regimen might lead to thrombosis event as they could cause major lipid disturbances [19]. Therefore, the autoantibody levels should be routinely tested in HIV patients to alert for thromboembolic events.

APS is the principal cause of thrombotic disease in the pediatric population [20]. When thrombosis occurs in children, especially if it coexists with HIV infection, APS should be considered. While comprehensive reviewing the literatures, only three cases of HIV in children with APS were currently reported [21, 22]. Out of which, two cases couldn't survive. Other patients that were reported thrombosis with APS and HIV were all adults [2, 7, 2325]. Good result was achieved in our case through aggressive anticoagulant therapy and high-dose corticosteroids therapy.

HIV may induce the occurrence of APS and promote life threatening thrombotic events through several mechanisms. Therefore, the autoantibodies levels should be routinely tested in HIV/AIDS patients, especially in patients with virological failure with high levels of HIV viremia.

\section{Abbreviations}

APS: Antiphospholipid Syndrome; VL: Viral Load; ART: Antiretroviral Therapy; aCLs: Anticardiolipin antibodies; LA: Lupus Anticoagulant; $\beta 2$ GPI: Anti-beta 2 glycoprotein I; WBC: White Blood Cell; Hb: Hemoglobin; APTT: Activated Partial Thromboplastin Time; INR: International Normalized Ratio: FIB: Fibrinogen; CRP: C-Reactive Protein; PCT: Procalcitonin; ESR: Erythrocyte Sedimentation Rate; pANCA: Anti-neutrophil cytoplasmic antibody; LMWH: Low Molecular Weight Heparin

\section{Acknowledgements}

Not applicable.

\section{Authors' contributions}

$R-J D, Y-Y L$, and Y-GZ contributed conception and design of the study. JL performed the statistical analysis. S-YL wrote the first draft of the manuscript. XPY wrote sections of the manuscript. The authors read and approved the final manuscript.

\section{Funding}

This work was partially supported by the Foundation of Scientific research Project of Yunnan Province education Department, China (2018JS251), Medical reserve personnel training plan of Yunnan Provincial Health Commission, China (H-2018104), the National Natural Science Foundation of China (81660737 and 81860553), The Joint Special Fund of Science and

Technology Department of Yunnan Province-Yunnan University of Chinese Medicine (2017FF117-003). The funding body have no role in the design of the study and collection, analysis, and interpretation of data and in writing the manuscript.

\section{Availability of data and materials}

Data sharing not applicable to this article as no datasets were generated or analyzed during the current study.

\section{Declarations}

Ethics approval and consent to participate

This study was approved by the Ethical Committee of the First Affiliated Hospital of Kunming Medical University (2018 L-45).

\section{Consent for publication}

All presentations of case reports have consent for publication.

\section{Competing interests}

The authors declare that they have no competing interests.

\section{Author details}

${ }^{1}$ Yunnan Provincial Hospital of Infectious Disease/Yunnan AIDS Care Center, Kunming 650301, China. ${ }^{2}$ Department of Dermatology and Venereology, First Affiliated Hospital of Kunming Medical University, Kunming 650032, China. ${ }^{3}$ College of Pharmaceutical Sciences, Yunnan University of Traditional Chinese Medicine, Kunming 650500, China. 
Received: 7 October 2020 Accepted: 15 March 2021

Published online: 25 March 2021

\section{References}

1. Abreu MM, Danowski A, Wahl DG, Amigo MC, Tektonidou M, Pacheco MS, et al. The relevance of "non-criteria" clinical manifestations of antiphospholipid syndrome: 14th International Congress on Antiphospholipid Antibodies Technical Task Force Report on Antiphospholipid Syndrome Clinical Features. Autoimmun Rev. [Journal Article; Research Support, Non-U.S. Gov't; Review]. 2015; 14(5):401-414.

2. Cervera R, Serrano R, Pons-Estel GJ, Ceberio-Hualde L, Shoenfeld Y, de Ramon E, et al. Morbidity and mortality in the antiphospholipid syndrome during a 10-year period: a multicentre prospective study of 1000 patients. Ann Rheum Dis. [Journal Article; Multicenter Study; Observational Study]. 2015; 74(6): 1011-1018.

3. Kiser KL, Badowski ME. Risk factors for venous thromboembolism in patients with human immunodeficiency virus infection. Pharmacotherapy. [Journal Article; Review]. 2010; 30(12): 1292-1302.

4. Schreiber K, Sciascia S, de Groot PG, Devreese K, Jacobsen S, Ruiz-Irastorza G, et al. Antiphospholipid syndrome. Nat Rev Dis Primers. [Journal Article; Review]. 2018; 4:17103

5. Schreiber K. Pregnancies in women with systemic lupus erythematosus and antiphospholipid antibodies. Lupus. [Journal Article; Research Support, NonU.S. Gov't; Comment]. 2016; 25(4):343-345.

6. Cervera R, Asherson RA, Acevedo ML, Gomez-Puerta JA, Espinosa G, De La Red G, et al. Antiphospholipid syndrome associated with infections: clinical and microbiological characteristics of 100 patients. Ann Rheum Dis. [Case Reports; Journal Article; Review]. 2004; 63(10):1312-1317.

7. Ramos-Casals M, Cervera R, Lagrutta M, Medina F, Garcia-Carrasco M, de la Red $\mathrm{G}$, et al. Clinical features related to antiphospholipid syndrome in patients with chronic viral infections (hepatitis C virus/HIV infection): description of 82 cases. Clin Infect Dis. [Journal Article]. 2004; 38(7): 10091016.

8. Abdel-Wahab N, Talathi S, Lopez-Olivo MA, Suarez-Almazor ME. Risk of developing antiphospholipid antibodies following viral infection: a systematic review and meta-analysis. Lupus. [Journal Article; Meta-Analysis; Review; Systematic Review]. 2018; 27(4): 572-583.

9. Asherson RA, Shoenfeld $Y$. The role of infection in the pathogenesis of catastrophic antiphospholipid syndrome--molecular mimicry? J Rheumatol. [Comment; Editorial]. 2000; 27(1): 12-14.

10. Shoenfeld Y, Blank M, Krause I. The relationship of antiphospholipid antibodies to infections--do they bind to infecting agents or may they even be induced by them? Clin Exp Rheumatol. [Editorial]. 2000; 18(4):431-432.

11. Karmochkine M, Ankri A, Calvez V, Bonmarchant M, Coutellier A, Herson S. Plasma hypercoagulability is correlated to plasma HIV load. Thromb Haemost. [Clinical Trial; Comparative Study; Letter; Research Support, Non-U. S. Gov't]. 1998; 80(1): 208-209.

12. Leder AN, Flansbaum B, Zandman-Goddard G, Asherson R, Shoenfeld Y. Antiphospholipid syndrome induced by HIV. Lupus. [Case Reports; Journal Article]. 2001; 10(5):370-374.

13. Zon LI, Groopman JE. Hematologic manifestations of the human immune deficiency virus (HIV). Semin Hematol. [Journal Article; Research Support, U. S. Gov't, P.H.S.; Review]. 1988; 25(3):208-218.

14. Martinez V, Diemert MC, Braibant M, Potard V, Charuel JL, Barin F, et al. Anticardiolipin antibodies in HIV infection are independently associated with antibodies to the membrane proximal external region of gp41 and with cell-associated HIV DNA and immune activation. Clin Infect Dis [Journal Article; Research Support, Non-U.S. Gov't]. 2009; 48(1): 123-132.

15. Galrao L, Brites C, Atta ML, Atta A, Lima I, Gonzalez F, et al. Antiphospholipid antibodies in HIV-positive patients. Clin Rheumatol. [Journal Article]. 2007; 26(11): 1825-1830.

16. Saif MW, Greenberg B. HIV and thrombosis: a review. Aids Pat Care Stds. [Journal Article; Review]. 2001; 15(1): 15-24.

17. Toulon P, Lamine M, Ledjev I, Guez T, Holleman ME, Sereni D, et al. Heparin cofactor II deficiency in patients infected with the human immunodeficiency virus. Thromb Haemost. [Journal Article; Research Support, Non-U.S. Gov't]. 1993; 70(5): 730-735.

18. Sorice M, Griggi T, Arcieri P, Circella A, D'Agostino F, Ranieri M, et al. Protein $\mathrm{S}$ and HIV infection. The role of anticardiolipin and anti-protein $\mathrm{S}$ antibodies. Thromb Res. 1994;73(3-4):165-75.
19. George SL, Swindells S, Knudson R, Stapleton JT. Unexplained thrombosis in HIV-infected patients receiving protease inhibitors: report of seven cases. Am J Med. 1999;107(6):624-30.

20. Heller C, Heinecke A, Junker R, Knöfler R, Kosch A, Kurnik K, et al. Cerebral venous thrombosis in children: a multifactorial origin. Circulation. 2003; 108(11):1362-7.

21. Shah I, Chudgar P. Antiphospholipid syndrome in a human immunodeficiency virus 1-infected child. Pediatr Infect Dis J. 2006;25(2):185-6.

22. Turhal N, Peters V, Rand J. Antiphospolipid Syndrome inHIV Infection Report on Four Cases and Review of Literature. Allerg Clin Immunol. 2001; 13:268-71.

23. Abdel-Wahab N, Lopez-Olivo MA, Pinto-Patarroyo GP, Suarez-Almazor ME. Systematic review of case reports of antiphospholipid syndrome following infection. Lupus. 2016;25(14):1520-31.

24. Hassoun A, Al-Kadhimi Z, Cervia J. HIV infection and antiphospholipid antibody: literature review and link to the antiphospholipid syndrome. AIDS Pat Care STDS. 2004;18(6):333-40.

25. Diaz JS, Octavio JG, Fernandez-Guerrero ML. Antiphospholipid syndrome and acute HIV infection. Emerg Infect Dis. 2010;16(2):360-1.

\section{Publisher's Note}

Springer Nature remains neutral with regard to jurisdictional claims in published maps and institutional affiliations.
Ready to submit your research? Choose BMC and benefit from:

- fast, convenient online submission

- thorough peer review by experienced researchers in your field

- rapid publication on acceptance

- support for research data, including large and complex data types

- gold Open Access which fosters wider collaboration and increased citations

- maximum visibility for your research: over $100 \mathrm{M}$ website views per year

At $\mathrm{BMC}$, research is always in progress.

Learn more biomedcentral.com/submissions 